Available online at: http://e-journal.upstegal.ac.id/index.php/jip

Submit: 04-08-2017; Revision: 29-o8-2017; Publish: 30-10-2017

\title{
UPAYA PEMERINTAH DALAM PENINGKATAN INDUSTRI BATIK BAKARAN DI KABUPATEN PATI MELALUI PROGRAM EKONOMI KREATIF
}

\author{
Usisa Rohmah ${ }^{1}$, Ardli Johan Kusuma² ${ }^{\text {, Fachry Rohilie }}{ }^{3}$ \\ 1 Program Studi Ilmu Pemerintahan Universitas 17 Agustus 1945 Jakarta. Jl. Sunter Permai \\ Raya No. 1. Sunter Agung Podomoro Jakarta Utara 14350. \\ 2 Program Studi Ilmu Hubungan Internasional Universitas 17 Agustus 1945 Jakarta. Jl. Sunter \\ Permai Raya No. 1. Sunter Agung Podomoro Jakarta Utara 14350. \\ 3 Program Studi Ilmu Pemerintahan Universitas 17 Agustus 1945 Jakarta. Jl. Sunter Permai Raya \\ No. 1. Sunter Agung Podomoro Jakarta Utara 14350. \\ * Korespondensi Penulis E-mail: ussy3@yahoo.co.id Telp. 085743368173
}

\begin{abstract}
Abstrak
Tujuan penulisan ini adalah untuk melihat potensi Batik Bakaran di kab. Pati, Jawa Tengah yang mengalami pasang surut dan belum mampu bersaing dengan batik daerah lainnya. Batik Bakaran kembali digalakkan melalui program pemerintah ekonomi kreatif agar mampu bersaing di industri tingkat nasional. Tulisan ini menggunakan metode kualitatif deskriptif, dengan teknik pengumpulan data, menggunakan teknik "Iibrarian research" dan "Interview". Hasil penelitian ini menunjukkan bahwa pemerintah sudah memberikan dukungan terhadap para pengrajin Batik Bakaran untuk melakukan pengembangan melalui pelatihan SDM untuk merangsang inovasi pengrajin batik dalam hal penciptaan motif dan warna Batik Bakara agar lebih diminati konsumen. Namun ternyata hal tersebut belum mampu meningkatkan daya saing Batik Bakaran di industri nasional. Solusi untuk mengatasi permasalahan tersebut adalah dengan meningkatkan kemampuan para pelaku industri batik bakaran yang meliputi: (1) kemampuan memperkokoh posisi pasarnya, (2) kemampuan menghubungkan dengan lingkungannya, (3) kemampuan meningkatkan kinerja tanpa henti, dan (4) kemampuan menegakkan posisi yang menguntungkan. Katakunci: Batik Bakaran, Ekonomi Kreatif, Industri Kreatif.
\end{abstract}

\section{Government Effort In Enhancing Batik Bakaran Industry In Pati Regency Through Creative Economic Program}

\begin{abstract}
The purpose of this paper is to see the potential Batik Bakaran in the district. Pati, Central Java which experienced ups and downs and has not been able to compete with other batik areas. Batik Bakaran is again encouraged through creative government economic program in in order to be able to compete in national level industry. This paper uses descriptive qualitative methods, with data collection techniques using "librarian research" and "interview" techniques. The results of this study indicates that the government has provided support to batik craftsmen. Government assistance is displayed by developing human resources through training to stimulate the innovation of batik craftsmen in terms of the creation of Batik Bakaran motifs and colors to be more attractive to consumers. But apparently it has not been able to improve the competitiveness of Batik Bakaran in the national industry. Solutions to overcome these problems is to apply the concept of competitiveness through the development of the capabilities of the batik Bakaran industry players include: (1) ability to strengthen its market position, (2) ability to connect with its environment, (3) ability to improve nonstop performance, and (4) ability to establish favorable position.
\end{abstract}

Keywords: Batik Bakaran, Creative Economy, Creative Industries 


\section{Jurnal Ilmu Pemerintahan, 2 (2), Oktober 2017 - 120}

Usisa Rohmah ${ }^{1}$, Ardli Johan Kusuma ${ }^{2}$, Fachry Rohilie ${ }^{3}$

\section{PENDAHULUAN}

Batik merupakan salah satu ekspresi budaya yang memiliki makna simbolis dan nilai estetika yang tinggi bagi masyarakat Indonesia. Keunikan dan keindahan batik merupakan salah satu pembentuk karakter bangsa yang membedakan produk batik yang kita miliki dengan bangsa lain sehingga dapat menjadi identitas dan jati diri bangsa (www.uph.edu, 2012). Batik dikatakan sebagai identitas bangsa Indonesia karena identitas merupakan hak untuk diakui. Begitupun dengan identitas batik Indonesia diakui karena batik sebagai identitas yang terus berkembang dan diakui.

Batik sudah diakui menjadi salah satu produk yang berkembang dalam ekonomi kreatif di Indonesia. Batik berkembang dan tumbuh di Indonesia sebagai manifestasi dari kekayaan budaya daerah pembatikan antara lain, batik khas Solo, Cirebon, Pekalongan, Lasem, Madura, Yogyakarta, dan lainnya baik Jawa maupun luar Jawa yang pada akhirnya tidak dapat dipisahkan dari ekspresi budaya suatu masyarakat pendukungnya terkait budaya daerah pembatikan (Aep, 2010).

Daerah pembatik memproduksi batik, corak dan motif satu sama lain berbeda-beda. Dalam pembatikan saling mempertahankan eksistensinya seperti ciri-ciri seni tradisi, proses teknologinya, dan selera konsumennya. Motif batik di daerah-daerah sampai sekarang masih kelihatan jelas unsur-unsur yang mempengaruhi pertumbuhannya, baik dari corak, warna, susunan, isian pada motif yang dilukiskan sampai pada penempatan hiasan. Dengan motif yang khas, batik di daerah-daerah itu bisa hidup tumbuh dan berkembang sebagai tradisi budaya.

Saat ini batik telah mendapat pengakuan dari United Nation Educational, Scientific, and Cultural Organizational (UNESCO). Masuknya batik dalam ekonomi kreatif merupakan tempat berkembangnya batik di Indonesia. Ekonomi kreatif merupakan era ekonomi baru yang berfokus pada kreativitas dan informasi. Dalam ekonomi kreatif, modal utama yang diperlukan adalah wawasan luas dan ide yang dimiliki Sumber Daya Manusia (SDM). Kedua modal tersebut merupakan faktor utama yang digunakan pembatik dalam menghadapi era ekonomi kreatif saat ini.

Konsep ekonomi kreatif ternyata mampu memberikan kontribusi nyata terhadap perekonomian di beberapa negara. Di Indonesia, ekonomi kreatif dimulai dari permasalahan akan pentingnya meningkatkan persaingan produk nasional untuk menghadapi pasar global. Salah satu tujuan dari ekonomi kreatif untuk menempatkan produk Indonesia, seperti batik menjadi produk yang berstandar internasional namun tetap memiliki karakter nasional yang diterima pasar dunia. Subsektor industri kreatif yang masuk ke dalam lingkup pembinaan Kementriaan Perindustrian adalah fashion, kerajinan, layanan komputer, dan piranti lunak. Fashion dan kerajinan merupakan merupakan subsektor yang dominan dalam memberikan kontribusi ekonomi. Salah satu bentuk industri kreatif fashion dan kerajinan di Indonesia terdapat di Kabupaten Jawa Tengah yaitu kabupaten Pati di wilayah Desa Bakaran Kulon, Kec. Juwana, yang memproduksi Batik 
Bakaran. Batik Bakaran merupakan salah satu kreativitas yang berjenis fashion yang masuk dalam pengembangan melalui ekonomi kreatif.

Banyak potensi yang menjadi ciri khas fashion batik lokal, batik Bakaran sudah banyak menyumbangkan komoditas batik dipasaran. Desa Bakaran yang menjadi sentra Batik Bakaran mampu menjadi ikon Kabupaten Pati dengan karya dan budaya masyarakatnya. Salah satu karya budaya masyarakat yang mempu menjadi perhatian masyarakat sejak luas adalah batik tulis batik Bakaran.

Sebelum reformasi dan terjadinya krisis ekonomi Batik Bakaran mampu berkembang dan cukup terkenal bahkan tidak kalah dengan produk batik lain seperti Batik Yogyakarta dan Solo. Adanya perubahan kondisi perekonomian serta melemahnya industri batik maupun pengrajin batik membuat Batik Bakaran mengalami kemerosotan dalam perkembangannya, sehingga tidak ada pilihan bagi industri Batik Bakaran untuk mengurangi produksinya dan menghilang dari pasaran. Pada tahun 2007 Batik Bakaran sudah mulai dikembangkan kembali, disaat industri batik lokal di daerah lain sudah berkembang seperti Solo, Yogyakarta, Pekalongan, Madura dan Lasem. Sehingga, Batik Bakaran juga harus mengembangkan kreativitasnya kembali agar dapat memenuhi kebutuhan dipasaran seperti sebelumnya.

Jika diperhatikan iklim usaha Batik Bakaran belum mengalami perkembangan yang begitu signifikan. Kreativitas dalam perkembangan desain motif batik Bakaran juga masih terbatas dengan ciri khas desain lokalnya. Kabupaten Pati merupakan salah satu kabupaten yang menyumbang komoditas batik dengan desain motif yang terbatas, membuat Batik Bakaran juga kurang memenuhi kebutuhan batik dipasaran. Memang sudah ada beberapa pengrajin batik yang sudah dapat bersaing dengan batik seperti Solo, Yogyakarta dan Pekalongan tetapi belum semua pengrajin batik bakaran mampu bersaing di industry nasional.

Kurangnya kreativitas pengrajin batik untuk mengolah motif Batik Bakaran yang sesuai dengan identitas lokal berakibat pada ketertingalan motif dan desain batiknya dengan kota-kota lainnya di Jawa Tengah seperti Solo, Pekalongan, dan Jepara. Kota-kota tersebut telah mengembangkan produksi batik lokalnya, sehingga masyarakat umum lebih mengenal produk lokal seperti Batik Solo, Batik Pekalongan, dan Ukiran Jepara.

Batik merupakan salah satu industri yang kembali digalakkan melalui program ekonomi kreatif agar produk batik Indonesia yang membawa nilai budaya lokal sesuai identitas kedaerahannya, mampu bersaing di tingkat industri nasional dan global. Pada kenyataannya batik bakaran masih belum mampu bersaing baik di industri nasional ataupun pasar global. Untuk itu tema ini sangat menarik untuk dikaji mengingat pemerintah sudah menggalakkan program ekonomi kreatif dimana industri batik menjadi salah satu target pemerintah untuk dikembangkan melalui program ekonomi kreatif tersebut. Penelitian ini ingin menganalisisi terhadap program pemerintah ekonomi kreatif dalam rangka peningkatan industri batik nasional khususnya batik Bakaran. 


\section{Jurnal Ilmu Pemerintahan, 2 (2), Oktober 2017 - 122}

Usisa Rohmah ${ }^{1}$, Ardli Johan Kusuma ${ }^{2}$, Fachry Rohilie ${ }^{3}$

\section{METODE}

\section{Jenis Penelitian}

Jenis penelitian yang dipakai adalah jenis penelitian kualitatif deskriptif yang mempelajari masalah-masalah yang ada serta tata cara kerja yang berlaku. Penelitian deskriptif kualitatif ini bertujuan untuk mendeskripsikan apaapa yang saat ini berlaku mengenai suatu fenomena secara terperinci dan memusatkan perhatian pada masalah yang bersifat aktual, yang pada akhirnya memberikan pemahaman yang lebih jelas mengenai fenomena yang diteliti.

\section{Waktu dan Tempat Penelitian}

Penelitian ini dilakukan pada bulan Februari hingga Juli 2017. Dengan tempat penelitian ini akan dilaksanakan di Desa Bakaran Kulon, Kecamatan Juwana, Pati, Jawa Tengah. Desa Bakaran merupan wilayah produsen pembuatan Batik Bakaran.

\section{Target/Subjek Penelitian}

Target dan subjek penelitian ini adalah yang bersangkutan terkait produsen/ Pengusaha Batik Bakaran di Desa Bakaran Kab. Pati Jawa Tengah dan Dinas Perdagangan dan Perindustrian Kab. Pati Jawa Tengah.

\section{Data, Intrumen, dan Teknik Pengumpulan Data}

Sumber data yang digunakan dalam penelitian ini terbagi kepada dua jenis, yaitu:

\section{Data Primer}

Sumber jenis data primer yang digunakan dalam penelitian ini berasal dari data yang diperoleh dari lokasi penelitian yaitu di pengrajin batik pengusaha batik bakaran di Desa Bakaran Kulon kab. pati, dan Disperindag Kab. Pati Jawa Tengah baik berupa hasil wawancara ataupun berkas/dokumen/surat Teknik Analisis Data yang peneliti dapatkan dari informan penelitian.

2. Data Sekunder

Sumber jenis data sekunder merupakan data-data yang peneliti dapatkan untuk mendukung data primer yang berasal dari buku-buku, hasil penelitian, seminar ataupun laporan terdahulu, buletin, jurnal, surat kabar, media online yang terkait dengan masalah penelitian.

\section{Analisis Data}

Analisa data menurut Patton adalah proses mengatur data, mengorganisasikan ke dalam suatu pola, kategori dan satuan uraian dasar sehingga dapat ditemukan tema dan dapat dirumuskan hipotesis kerja seperti yang disarankan dalam data (Lexy, 2002: 165). Penganalisaan data atau pemeriksaan keabsahan data, dalam penelitian ini menggunakan metode trianggulasi sumber yaitu tekinik pemeriksaan data yang memanfaatkan sesuatu yang lain diluar data untuk keperluan pengecekan atau sebagai pembanding terhadap data itu.

Teknik analisa data dalam penelitian ini meliputi:

a. Reduksi data.

Reduksi data dapat diartikan sebagai proses pemilihan, pemusatan perhatian pada penyederhanaan, pengabstrakan, dan transformasi data yang muncul dari catatancatatan hasil penelitian lapangan. Reduksi data dapat juga diartikan dengan merangkum, memilah-milah data, dan menyusun data secara sistematis melalui kegitan ini maka 


\section{Jurnal Ilmu Pemerintahan, 2 (2), Oktober 2017 - 123}

Usisa Rohmah ${ }^{1}$, Ardli Johan Kusuma ${ }^{2}$, Fachry Rohilie ${ }^{3}$

peneliti dapat menarik kesimpulan final.

b. Penyajian Data

Dalam tahap ini berbagai data yang telah terkumpul dan dianggap penting maka akan dianggap penting maka akan digambarkan dalam bentuk deskripsi untuk mempermudah melihat gambaran keseluruhannya sehingga dapat membantu merumuskan kesimpulan yang tepat.

c. Pengambilan kesimpulan secara kualitatif atau verifikasi. Verifikasi merupakan langkah terakhir dalam kegiatan analisa kualitatif. Penarikan kesimpulan ini tergantung pada besarnya kesimpulan catatan data tersebut

\section{HASIL DAN PEMBAHASAN}

\section{Posisi Batik Bakaran Dalam Persaingan Industri Pasar Nasional}

Batik merupakan wujud karya seni yang dituangkan dalam motif kain kebanggaan warisan Bangsa Indonesia khususnya Batik Bakaran. Batik di Indonesia merupakan salah satu warisan leluhur yang membudaya dan disukai oleh semua kalangan, dari anak-anak sampai orang tua. Sehingga wajar jika batik saat ini sudah mulai ditemuai dikota-kota besar seperti Solo, Surakarta, Pekalongan, Yogyakarta, Cirebon dan di Kab. Pati yang terkenal dengan Batik Bakaran. Tentunya daerah pembatik yang menjadi sentra industri dapat meningkatkan perekonomian wilayahnya serta meningkatkan perekonomian Indonesia.

Industri batik dapat mengangkat negara Indonesia di kancah internasional dengan motif batik yang khas sesuai dengan kedaerahannya masing-masing. Contoh Batik Bakaran yang ada dikabupaten Pati ciri khasnya dengan motif yang retak-retak atau pecah-pecah yang mirip pecahnya tanah dimusim kemarau yang panjang. Kerajinan batik di Desa bakaran mengambarkan ciri khas batik pesisir.

Dengan banyaknya motif batik mengambarkan bahwa negara Indonesia memiliki hak cipta dalam budaya batik. Meskipun ada beberapa negara lain seperti China, Malaysia juga mampu menciptakan batik modern. China yang terkenal dengan motif batik bunga-bunga dengan ciri khas warna merah, Malaysia terkenal dengan warna kuning. Perbedaaan batik Nusantara dengan batik negara-negara lainnya itu tidak dilihat dari warna ataupun motifnya.

Perbedaan batik nusantara dengan batik negara lainnya terletak pada proses pembuatannya, seperti batik Indonesia, diantaranya Batik Bakaran dibuat melalui proses yang masih tradisional dengan alat-alat tradisional seperti canting, lilin atau malam, serta pewarnaannya pun masih mengunakan pewarna alami yang mengandalkan sumber daya alam sehingga prosesnya pun membutuhkan waktu yang relatif lama, bahan yang digunakan untuk membuat Batik Bakaran dengan mengunakan kain mori melalui proses yang masih tradisioanal inilah kemudian UNESCO mengangap batik sebagai warisan budaya karena ini ada hanya di Indonesia. Apalagi batik Bakaran yang masih kental dengan sejarah tidak terlepas dari kerajaan Mataram dan Majapahit.

Batik Bakaran menjadi potensi unggulan Kab. Pati, hanya saja potensi tersebut belum dikelola secara maksimal. 
Batik bakaran masih sebatas digunakan untuk cenderamata dan produk unggulan di Kab. Pati.

Perkembangannya Batik Bakaran mengalami pasang surut. Batik Bakaran memang tidak seterkenal batik Yogyakarta, batik Lasem, Solo dan Pekalongan. Hal itu disebabkan karena pada saat itu Desa Bakaran adalah desa yang terisolir, sehingga tidak banyak orang yang datang ke Desa Bakaran.

Pada Tahun 1960-an industri Batik Bakaran sudah mati karena semakin sedikit orang yang tertarik untuk membatik. Sampai pada tahun 1983 Batik Bakaran muai mendapat binaan dari Dinas Perindustrian dan Perdagangan (Disperindag) Kab. Pati yang mempunyai peran membatu industri pengrajin batik Bakaran untuk mengembangkan batik melalui pelatihan kilat (Diklat) (Purwaningtyas, 2014). Tujuan tersebut untuk meningkatkan kualitas Batik Bakaran agar menarik konsumen.

Batik bakaran mengalami kemerosotan kembali pada tahun 1998 karena krisis moneter. Harga bahan baku batik yang melonjak membuat industri batik tidak memproduksi batiknya kembali. Dan pada tahun 2004 ada seorang pengrajin Batik Bakaran mengusulkan Batik Bakaran digunakan sebagai sragam PNS di Kab. Pati, namun usulan tersebut ditolak baru pada tahun 2006 usulan tersebut diterima untuk menyelamatkan batik Bakaran sebagai warisan Budaya yang mencirikan kekhasan daerah (www.travel.tempo.com , 2013). Dengan adanya aturan pemakain batik Bakaran sebagai seragam PNS Kab. Pati Pemerintah akan senantiasa ikut mendukung industri pengrajin Batik bakaran tetap meningkatkan produksinya agar dapat menarik wisatawan dalam negeri ataupun luar negeri untuk berkunjung ke kab. Pati.

Sejak tahun 2006 pangsa pasar Batik Bakaran mulai meningkat dengan pesat bahkan batik Bakaran sudah diminati masyarakat luar daerah. Melalui promosi Disperindag Kab. Pati dan melalui promosi dari mulut ke mulut antar konsumen. Selain itu banyaknnya pengusaha batik baru pun bermunculan karena banyaknya permintaan masyarakat terhadap Batik Bakaran. Sebagian pengrajin batik sudah memasarkan Batik Bakaran melalui media online, agar memudahkan konsumen untuk membeli batiknya dan memudahkan penjualan batik keluar daerah.

Seorang pengrajin Batik Bakaran yang bernama Bukhori warga Desa Bakaran Kulon, juga sebagai pengusaha batik Bakaran dia menuturkan bahwa penjualan batik bakarannya sudah mulai merabah ke berbagai daerah dan mampu bersaing dengan Batik Lasem, Yogyakarta, Solo, Kudus dan Pekalongan (travel.tempo, 2013). Hal ini membuktikan memang sudah ada peningkatan dalam penjualan ke tingkat pasar nasional dan Batik Bakaran digemari berbagai konsumen di berbagai wilayah.

Pemasaran Batik Bakaran sudah banyak menunjukkan perkembangan yang baik di pasar nasional dengan permintaan batik yang cukup tinggi. Hal ini ditandai dengan meningkatnya jumlah pedagang dan pengusaha batik bakaran, bahkan sebagian besar pedagang memasarkan batik bakaran ke toko-toko di pusat perbelanjaan kota-kota besar diantaranya pusat perbelanjaan Thamrin 
City di kawasan Jakarta Pusat. Meningkatnya penjualan Batik Bakaran di tingkat Nasional karena batik bakaran memiliki karakter dan keunikan yang bermotif retak-retak yang menyerupai tanah kering dimusim kemarau.

Hal ini membuktikan persaingan Batik Bakaran sudah mampu bersaing dengan daerah lainnya. Meski tidak semua pengrajin batik Bakaran mampu menembus Pasar Nasional dan Internasional, hanya sebagian pengrajin Batik Bakaran yang mampu bersaing ditingkat Lokal dan internasional. Dalam hal persaingan sebenarnya antar sesama pengrajin Batik Bakaran saling bersaing untuk memperluas pasarannya.

Setiap pengrajin batik Bakaran mempunyai kemampuan yang berbeda beda, pengrajin batik bakaran yang belum mampu bersaing dipasaran tingkat Nasional dan internasional dapat disebabkan dari segi motif/desain yang monoton serta kualitas pewarnaan yang kurang diminati masyarakat. Selain itu banyak pengrajin batik bakaran yang belum memiliki kemampuan untuk menciptakan inovasi desain baru. Hanya beberapa yang mampu, sedangkan pengrajin batik lainnya hanya menjiplak desain yang sudah ada sebelumnya.

Sejak batik bakaran masuk kedalam ekonomi kreatif tahun 2009 para pengrajin batik bakaran mendapat pelatihan dari pemerintah Kab. Pati untuk melakukan inovasi. Saat itu para pengrajin batik bakaran sudah memulai melalukan inovasi dalam hal pewarnaan sehingga banyak motif batik bakaran bermotif modern dan berwarna cerah. Selain itu pengusaha batik bakaran juga mulai mengembangkan sejumlah motif maritim yang banyak diminati konsumen di kalangan nasional. Hal ini karena mempunyai keunikan dalam hal variasi dan kombinasi warna cerah yang saat ini diminati konsumen dipasaran, selain itu pengusaha dan pedagang batik tetap menyediakan motif klasik untuk dipasarkan ke segmen tertentu (Koranmuria, 2017).

Batik Bakaran mulai diminati di pasar nasional karena banyak melakukan inovasi dengan penciptaan motif baru dan tetap mempertahankan motif pesisiran/ motif retak-retak dengan warna dasar gepal seperti hitam dan cokelat, sedangkan untuk warna dan motif yang lebih modern/kontemporer masih dalam pengembangan melalui pameran dan lomba antar pengrajin batik. Sebagian motif Batik Bakaran sudah dipatenkan diantaranya motif beras kececer dan sidomukti yang merupakan motif khas bakaran. Pemerintah Kab. Pati membantu untuk mematenkan motif tersebut.

\section{Program Ekonomi Kreatif}

Ekonomi Kreatif pertama kali digagas oleh Inggris (John Howkins, 2001) dalam bukunya "Creative Economy, How People Make Money From Ideas". Menurut Howkins ekonomi kreatif adalah aktivitas perekonomian yang lebih mengandalkan ide atau gagasan (kreatif) untuk mengelola material yang bersumber dari lingkungan sekitar menjadi bernilai tambah ekonomi. Dalam ekonomi kreatif yang harus dikembangkan adalah ide kreatif manusia (masyarakat) yang digunakan untuk mengubah kualitas hidup menjadi lebih sejahtera. Ekonomi kreatif lebih mengandalkan kreativitas individu melalui gagasan, daya kreasi, dan daya cipta untuk meningkatkan nilai tambah ekonomi karyanya, sehingga 


\section{Jurnal Ilmu Pemerintahan, 2 (2), Oktober 2017 - 126}

Usisa Rohmah ${ }^{1}$, Ardli Johan Kusuma ${ }^{2}$, Fachry Rohilie ${ }^{3}$

mampu menciptakan lapangan kerja dan kesejahteraan.

Berdasarkan data yang diperoleh melalui BPS tahun 2015, industri ekonomi kreatif terdiri dari 15 kategori, namun hanya terdapat tiga kategori yang menyumbang secara signifikan kepada produk domestic bruto yaitu indutsri fashion, industri kerajinan dan periklanan (www.pikiran-rakyat.com, 2017).

Subsektor industri kreatif yang masuk kedalam pembinaan Kementrian Perindustrian salah satunya adalah fashion, kerajinan, peranti lunak dan layanan komputer, tetapi yang merupakan subsektor dominan dalam memberikan kontribusi ekonomi adalah fashion dan kerajinan. Fashion dan kerajinan menjadi hal utama dalam pengembangan ekonomi kreatif di Indonesia, keduanya mampu mengungguli kontribusi jenis industri kecil lainnya, yang berupa tenaga kerja, jumlah perusahaan maupun ekspornya. Salah satu bentuk industri kreatif yang mendapat dukungan pemerintah melalui progran ekonomi kreatif yang berupa fashion dan kerajinan yang terdapat di Desa bakaran Kabupaten Pati, Jawa Tengah yaitu Batik Bakaran. Batik Bakaran mempunyai ciri khas lokal kedaerahannya. Dalam pengembangan motifnya pun tidak meningalkan unsur budaya lokal.

Batik Bakaran merupakan wujud karya seni yang dituangkan dalam motif kain kebanggaan warisan Bangsa Indonesia. Batik mempunyai daya tarik tersendiri yang dapat menarik pengujung wisatawan domestik maupun internasional. Batik Bakaran merupakan salah satu warisan leluhur yang membudaya. Sejarah keberadaan Batik
Bakaran lekat dengan Legenda tentang tokoh Nyi Danowati yang merupakan seorang tokoh abdi dalam yang bertugas membuat pakaian prajurit dari kerajaan Majapahit, Ia datang ke Desa Bakaran untuk mencari tempat persembunyian karena dikejar-kejar oleh prajurit Demak. Nyi Danowati (salah satu pengikut Brawijaya) yang beragama Hindu. Memilih meningalkan Majapahit karena tidak mau masuk Islam. Saat itu Kerajaan Majapahit diperintahkan oleh Girindra wardana yang bergelar Brawijaya VI (1478-1498) berada dalam desakan Kerajaan Demak yang menganut Islam (www.patikab.go.id, 2014).

Di Desa Bakaran itulah Nyi Danowati membuka pemukiman baru, Ia juga membangun mushola tanpa mihrab yang disebut Sigit. Dipelataran itulah Nyi Danowati mengajarkan warga membatik. Keberadaan Nyi Danowati sebagai danyang atau nenek moyang dan pengajar batik pertama di lingkungan Bakaran. Motif batik yang diajarkan Nyi Danoewati adalah motif batik Majapahit. Diantaranya, sekar jagat, padas gempal, magel ati, dan limaran. Motif khusus yang diciptakan Nyi Danowati sendiri adalah motif gandrung (www.patikab.go.id, 2004). Saat ini warga Bakaran selain melestarikan motif Nyi Danowati, mereka juga mengembangkan aneka macam motif kontemporer, antara lain motif pohon druju (juwana), gelombang cinta, kedele kecer, jambu alas, dan blebak urang. Saat ini Batik Bakaran sudah mulai mengembangkan batiknya yang terdiri dari batik klasik dan batik kontemporer.

Batik Bakaran sangat dekat dengan sisi ekonomi. Artinya industri Batik Bakaran selalu disandingkan dengan isuisu ekonomi. Karena memang tidak bisa 
dipungkiri di saat ini industri Batik Bakaran telah memberikan manfaat ekonomi bagi masyarakat pengrajin Batik Bakaran khususnya di Desa bakaran. Bahkan, semenjak batik disahkan sebagai warisan budaya asli Indonesia oleh United Nation Education Scientific and Cultural Organization (UNESCO) pada 2 Oktober 2009, maka industri batik di Indonesia semakin mengalami perkembangan yang cukup signifikan. Menurut Data Kementerian Perindustrian menunjukkan bahwa ada 47.755 unit IKM batik yang ada di Indonesia, jumlah IKM tersebut telah menyerap jumlah tenaga kerja yang terlibat mencapai 199.444 orang (Detikfinance, 2017). Jumlah tersebut menunjukkan bahwa memang industri batik dalam negeri selalu erat kaitannya dengan dimensi ekonomi. Karena memang banyak orang Indonesia yang menggantungkan perekonomiannya dalam sektor perindustrian batik dalam negeri.

Pengemangan batik bakaran melalui program ekonomi kreatif harus mengacu pada Intruksi Presiden No. 6 tahun 2009 tentang pengembangan ekonomi kreatif tahun 2009-2015. Ekonomi kreatif sangat diperlukan untuk mendorong daya saing Batik Bakaran lebih kuat dan berkualitas sehingga mampu bersaing di tingkat global. Batik Bakaran merupakan produk unggulan kab. Pati, dengan menampilkan ciri khas kedaerahan yang dituangkan menjadi motif Batik Bakaran dan menjadi potensi keunikan dari Batik Bakaran. Dengan masuknya batik bakaran melalui program ekonomi kreatif diharapkan dapat meningkatkan daya saing batik di kancah internasional dan dapat meningkatkan kesejahteraan masyarakat daerah pembatik seperti Solo, Pekalongan dan Jepara.

Pengembangan Batik Bakaran sejak 2007 memang sudah mengalami perkembangan yang cukup baik bila dibandingkan dengan tahun sebelumnya. Apalagi semenjak Batik Bakaran masuk dalam daftar ekonomi kreatif dengan dukungan pemerintah kabupaten pati, dukungan pemerintah agar adanya kenaikan potensi dalam pejualan batik melalui beberapa program seperti pameran batik yang diselengarakan rutin setiap 1 tahun sekali oleh Dinas Koperasi dan UMKM Kab. Pati, untuk meningkatkan daya beli masyarakat terhadap batik bakaran. Seperti adanya pasar Pragolo turut mendorong pengrajin batik untuk berani menyediakan stok batik, sehingga produksi pengrajin batik bakaran meningkat.

Adanya pameran batik bakaran serta pasar pragolo merupakan wujud dari dukungan pemerintah Kab. Pati untuk meningkatkan produksi batik serta berujung kepada peningkatan kesejahteraan masyarakat pengrajin. Selain pemerintah menyelengarakan pameran batik, pemerintah juga menyediakan stand gratis bagi pelaku usaha untuk memasarkan batiknya. Penjualan batik bakaran rata-rata dijual dengan harga yang bervariasi, untuk kisaran harga batik bakaran yaitu antara 100-400 ribu rupiah, sesuai dengan jenis dan kualitasnya. Untuk jenis batik sendiri mempunyai dua jenis yaitu batik klasik biasanya paling mahal karena memiliki motif yang rumit sehingga proses pengerjaan juga lama. Waktu yang dibutuhkan untuk memproduksi batik bakaran jenis klasik yaitu antara 1-2 minggu, dan jenis batik kontemporer 
seperti motif pohon druju (juwana), gelombang cinta, kedele kecer, jambu alas, dan blebak urang yang membutuhkan waktu pengerjaan batiknya dibutuhkan waktu 5-7 hari.

Dukungan pemerintah melalui program ekonomi kreatif untuk meningkatkan produktivitas batik bakaran tidak hanya dengan menyediakan fasilitas penjualan bagi pelaku usaha batik tetapi juga dengan meningkatkan kualitas SDM pengrajin batik. Ada beberapa dukungan dari pemerintah seperti bantuan pelatihan manajemen penjualan, pelatihan promosi, pewarnaan batik bakaran.

Pertama, dukungan pemerintah melalui pelatihan manajemen usaha ini diharapkan dapat meningkatkan pangsa pasar Batik Bakaran, karena permintaan akan kebutuhan masyarakat terhadap batik meningkat. Hal ini juga disertai dengan dukungan pemerintah Kab. Pati dengan mewajibkan PNS memakai seragam Batik Khas Pati untuk mendukung pengrajin batik dalam melakukan pengembangannya. Motif yang dipesan bagi PNS Kab. Pati adalah motif batik pati bumi mina tani. Salah satu alasan pemerintah Kab. Pati mewajibkan PNS untuk memakai batik bakaran adalah sesuai dengan kearifan lokal sesuai daerah masing-masing. Pelaku usaha batik pun merasakan kenaikan pendapatan dengan program PNS yang mewajibkan pemakaian batik bakaran untuk penguatan kearifan lokal.

Kedua, pelatihan promosi. Keberhasilan dalam mempromosikan batik bakaran merupakan salah satu hal terpenting dalam peningkatan penjualan batik bakaran. Strategi yang tepat baik diwilayah setempat ataupun diluar daerah dengan standarisai produk batik bakaran melalui pemasaran sistem online. Ada sebagian pengusaha batik bakaran memasarkan batik bakaran melalui instagram, merupakan salah satu media online yang tepat untuk mempromosikan batik bakaran ke daerah luar. Karena media online merupakan media yang murah dan dapat menjangkau semua wilayah, dalam hal ini yang dibutuhkan adalah ketrampilan cara berkomunikasi dengan pihak pembeli dan akses terhadap tehnologi komunikasi dengan mengunakan HP dan komputer.

Ketiga, pewarnaan batik bakaran. Batik bakaran merupakan salah satu batik tradisional dengan visual ragam hias yang sederhan. Dalam pewarnaan Batik Bakaran pun masih terbatas hanya mengunakan warna gelap. Pewarnaan batik bakaran pun menggunakan warna yang matang dan kontras seperti batik pedalaman karena pengaruh yang dibawa oleh Nyai Ageng Danowati di Desa Bakaran. Saat itu hanya mampu membuat warna itu. Warna biru dilarang karena proses pencampuran bahan pewarna mengunakan sepotong daging ayam.

Saat ini pemerintah Kab. Pati sudah memberikan pelatihan pewarnaan, melalui teknologi pewarnaan yang dapat menghasilkan teknik pewarnaan menjadi beraneka ragam. Pelatihan teknik pewarnaan dan pelatihan skill yang dibarengi dengan bakat yang dimiliki pengrajin batik bakaran. Dengan pelatihan ini sudah mulai dapat mengembangkan motif dan warna sehingga mirip batik pesisir yang lain, dalam pewarnaannya pun sudah mulai memberikan warna cerah, kuat dengan identitas batik bakaran dan beraneka ragam. 


\section{Jurnal Ilmu Pemerintahan, 2 (2), Oktober 2017 - 129}

Usisa Rohmah ${ }^{1}$, Ardli Johan Kusuma ${ }^{2}$, Fachry Rohilie ${ }^{3}$

Selain

pelatihan

pewarnaan

pemerintah Kab. Pati melalui DISPERINDAG juga pernah mengadakan kegiatan kunjungan lapangan/ studi banding ke Solo, Jogja maupun Pekalongan untuk mempelajari proses pewarnaan batik yang dihasilkan dari daerah-daerah tersebut. Sebagaimana diketahui kalau batik dari daerah-daerah tersebut merupakan batik berkualitas yang sudah dikenal luas.

Kunjungan/studi bandinng dalam pelatihan pewarnaan dimaksudkan untuk mempelajari proses pewarnaan sehingga dapat meningkatkan kualitas warna pada Batik Bakaran agar lebih awet dan tidak cepat luntur. Selain kunjungan lapangan ke daerah penghasil batik, Pemerintah kab. Pati juga mengajak beberapa pengrajin Batik Bakaran untuk studi banding ke Jember dalam festival batik bertaraf internasional.

Jika diperhatikan iklim usaha Batik Bakaran belum mengalami perkembangan yang begitu signifikan. Kreativitas dalam perkembangan desain motif batik Bakaran juga masih terbatas dengan ciri khas desain lokalnya. Kabupaten Pati sebagai sentra Batik Bakaran menyumbang komoditas batik dengan desain motif dan pewarnaan yang terbatas, membuat Batik Bakaran masih kalah bersaing dengan batik dari daerahdaerah lainnya yang dapat memenuhi kebutuhan konsumen terkait motif dan warna pada batiknya.

$$
\text { Adanya bantuan pelatihan }
$$
pewarnaan dari Disperindag Kab. Pati diharapkan dapat membatu para pengusaha Batik Bakaran untuk meningkatkan kreativitas pewarnaan Batik Bakaran serta dapat meningkatkan penjualan serta pemasaran Batik
Bakaran. Dengan adanya pelatihan pewarnaan serta kunjungan ke daerahdaerah batik dan mengikutsertakan pameran Batik diharapkan dapat mendorong pengrajin batik untuk lebih inovatif serta meningkatkan kualitas sumber daya manusianya.

Hasil analisis dari penelitian ini membuktikan program ekonomi kreatif memang dapat meningkatkan kualitas serta produksi Batik Bakaran. Bila dibandingkan sebelum adanya ekonomi kreatif, para pengrajin memproduksi batik dengan kemampuan dan peralatan seadanya. Sedangkan setelah adanya ekonomi kreatif, pengrajin batik lebih aktif untuk menyampaikan apa yang menjadi kebutuhannya kepada pemerintah Kab. Pati untuk mengembangkan Batik Bakaran. Pengrajin batik sudah mengetahui tentang apa yang menjadi hambatan dalam pengembangan Batik Bakaran, sehingga ketika akan mengembangkan batik pun mereka akan lebih mengetahui apa yang harus dilakukan oleh pengrajin batik bakaran.

Pengrajin batik belajar ke daerahdaerah lain yang industri batiknya lebih maju, terutama dalam hal teknologi. Hal ini turut membantu mengembangkan industri batik bakaran dalam pewarnaan melalui teknologi serta mendorong kemajuan lewat promosi/penjualan dengan teknologi yang berupa media sosial, ataupun mencari referensi motif batik melalui teknologi sehingga dalam pengengembangan motif pun dapat lebih bervariasi.

Program ekonomi kreatif Batik Bakaran dapat mendorong munculnya pengrajin-pengrajin batik baru dengan ide-ide yang lebih kreatif, meningkatnya 


\section{Jurnal Ilmu Pemerintahan, 2 (2), Oktober 2017 - 130}

Usisa Rohmah ${ }^{1}$, Ardli Johan Kusuma ${ }^{2}$, Fachry Rohilie ${ }^{3}$

permintaan barang sehingga perekonomian masyarakat pengrajin batik meningkat, serta meningkatkan sarana prasarana dalam memproduksi batik yang jauh lebih baik. Pengrajin batik pun sudah banyak yang mempunnyai rumah produksi sendiri, perkembangan usaha produksi batiknya sudah mulai berkembang ke daerah lain.

Perkembangan Batik Bakaran sudah menunjukkan peningkatan dalam produksi serta penjualan. Namun, setiap pengrajin batik mempunyai wilayah pemasaran yang berbeda-beda. Seperti pengrajin Batik Bakaran Bapak Bukhori yang sudah sering mendapat pesanan dari berbagai kota dan sudah dapat bersaing dengan daerah pembatik lainnya seperti Solo, Yogyakarta, Pekalongan, Kudus dan Lasem. Bahkan pemasaran Batiknya sudah mencapai Amerika Serikat dan Kanada (travel.tempo, 2013).

Hal ini membuktikan permintaan terhadap Batik Bakaran dari berbagai daerah sangat tinggi, dalam hal persaingan Batik Bakaran sudah mampu bersaing dengan daerah lainnya. Meski tidak semua pengrajin batik Bakaran mampu menembus Pasar Nasional dan Internasional, hanya sebagian pengrajin Batik Bakaran yang mampu bersaing ditingkat Lokal dan internasional.

Program ekonomi kreatif dari pemerintah dapat berpengaruh terhadap pengrajin batik khususnya luasnya pangsa pasar, terutama untuk pengrajin yang mampu mengembangkan SDM dengan berinovasi dan menciptakan motif baru batik bakaran yang sesuai dengan minat konsumen dipasaran. Bertambah luasnya pangsa pasar dapat meningkatkan kesejahteraan pengrajin batik. Rata-rata setiap pengrajin batik sudah mengalami peningkatan dalam hal pendapatan, seperti pengrajin batik Ibu Juwati saat ini pendapatannya mencapai 30-40 juta perbulan, pendapatan ini jauh meningkat apabila dibandingkan saat sebelum adanya bantuan dari pemerintah. Sedangkan pengrajin Batik bakaran seperti Bapak Bukhori yang pangsa pasar batiknya sudah dapat bersaing dengan daerah pembatik lainnya seperti Solo, Yogyakarta, Pekalongan hingga sampai ke internasional rata-rata omset perbulan 60 juta (travel.tempo, 2013).

\section{Faktor Penghambat Perkembangan}

Batik Bakaran sangat membutuhkan perhatian dari pemerintah dan masyarakat melalui program ekonomi kreatif agar dapat bersaing bersama pelaku ekonomi pembatik seperti daerah batik lainnya, dan batik Bakaran lebih dikenal di luar daerah dan dapat bersing dikancah internasional.

Pengembangan batik bakaran melalui program ekonomi kreatif belum berorientasi pada kualitas sumber daya manusia (minimnya inovasi), kegiatan ekonominya masih terbatas pada sulitnya pengrajin batik bakaran dalam (1) kemampuan memperkokoh posisi pasarnya, (2) kemampuan menghubungkan dengan lingkungannya, (3) kemampuan meningkatkan kinerja tanpa henti, dan (4) kemampuan menegakkan posisi yang menguntungkan.

Program pengembangan batik bakaran melalui ekonomi kreatif belum sepenuhnya mengoptimalkan kompetensi sumber daya manusia (SDM) lokal. Modal utama dalam pengembangan Batik Bakaran dalam meningkatkan daya saing melalui ekonomi kreatif sangat 
diperlukan wawasan yang luas serta ide yang dimiliki oleh pengrajin batik dalam membuat motif batik sesuai warna dengan selera yang diminati pasaran. Minimnya kreativitas salah satunya disebabkan karena keterbatasan inovasi dari pengrajin batik serta minimnya pelatihan dalam pembuatan batik.

$$
\text { Pengembangan Batik Bakaran }
$$

melalui program ekonomi kreatif sangatlah membutuhkan kreativitas SDM didalamnya. SDM yang terlibat harus mampu menuangkan ide atau mencetuskan ide kreativitas yang dimilikinya. Itulah wujud atau aksi atas program ekonomi kreatif yang digalakkan oleh pemerintah untuk membangun masyarakat melalui peningkatan kualitas SDM yang dapat meningkatkan kesejahteraan masyarakat.

Lemahnya SDM pengrajin batik Bakaran sangat terlihat dari cara mereka memasarkan batiknya, penjualan batik rata-rata masih menunggu pembeli datang, mereka jarang memanfaatkan teknologi dalam memperluas akses pasar batik bakaran, hal ini membuktikan masih lemahnya pengrajin batik bakaran terhadap akses teknologi. Lemahnya SDM pengrajin batik bakaran juga kurang mengetahui kendala atau kelemahan yang mereka hadapi terhadap pengembangan industri batiknya. Seperti saat peneliti melakukan wawancara dengan salah satu pelaku usaha batik bakaran yaitu Ibu Yahyu, ketika ditanya terkait kendala apa saja yang dihadapi dalam mengembangkan industri batik bakaran, beliau masih belum bisa menganalisa terkait kedala apa saja yang dihadapi. Hal itu menandai bahwa tingkat kemampuan SDM untuk menganalisis terkait kelebihan dan kekurangan yang ada pada industri batik bakaran yang digeluti masih sangat kurang. Itu artinya pengembangan SDM sangat mutlak diperlukan apabila pemerintah serius ingin mengembangkan industri batik bakaran.

Lemahnya SDM pengrajin batik bakaran membuat minimnya inovasi pada pengrajin batik bakaran membuat sebagian besar pengrajin dalam pengembangan batik masih berorientasi pada pemanfaatan sumber daya alam (SDA), hal ini dapat terlihat dalam penciptaan warna pada motif kain batik bakaran yang rata-rata berwarna gelap. Berikut adalah contoh jenis motif Batik Bakaran:

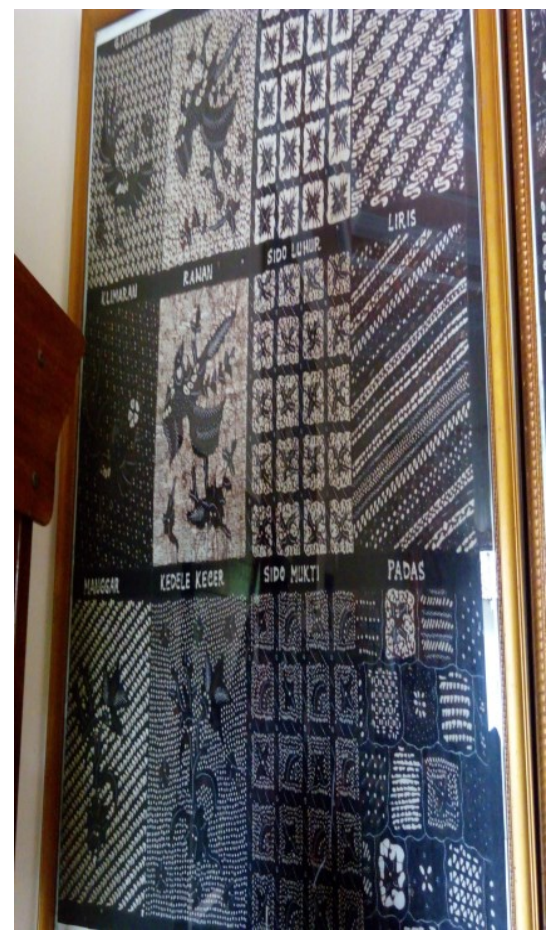

Gambar 1. Motif Batik Bakaran

Sumber Gambar: Foto dokumentasi penelitian (diambil saat Ekspo Koperasi dan Gelar Bazar Batik Bakaran Kab. Pati tanggal 22 Juni 2017). 


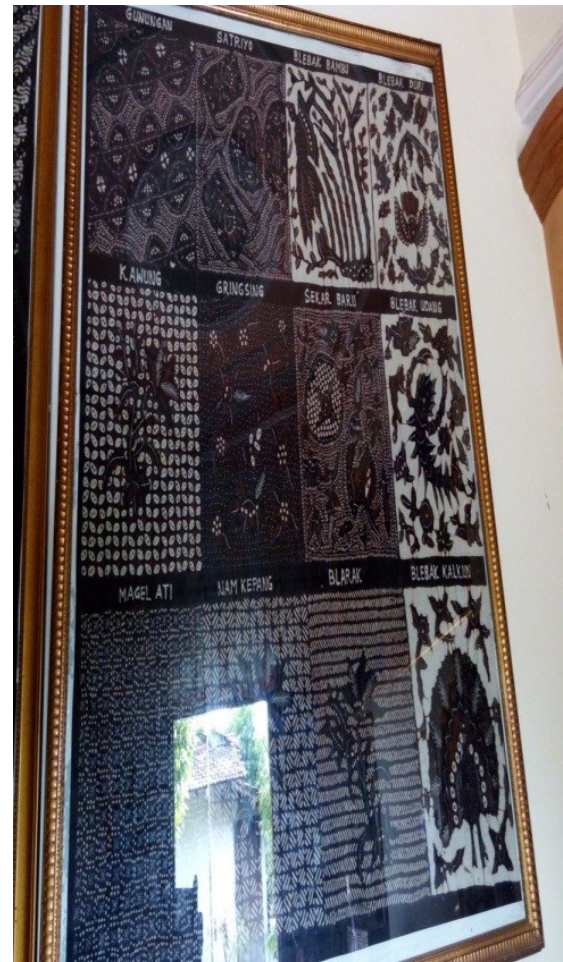

Sumber Foto: dokumentasi penelitian (diambil saat Ekspo Koperasi dan Gelar Bazar Batik Bakaran Kab. Pati tanggal 22 Juni 2017).

Menurut Bapak Sutopo, Rata-rata motif batik klasik Bakaran memiliki nuansa gelap karena masih terbatasnya dalam pengembangan pewarnaan yang masih menanfaatkan larutan pewarna berasal dari tumbuh-tumbuhan. Seperti, kulit pohon tingi yang menghasilkan warna coklat, kayu tegoran warna kuning, dan akar kudu warna sawo matang. Zat pewarna batik bakaran banyak memanfaatkan akar, kulit akar, batang, daun, bunga maupun getah tumbuhan, yang harus diolah terlebih dahulu sehingga menghaslikan warna dalam pewarnaan batik Bakaran. Bahan-bahan pewarna itu sudah sulit ditemui. Sehingga dalam pengembangan motif Batik bakaran menyebabkan minimnya motif pada batik serta corak warnanya, dan kurang mengikuti tren yang berkembang, sehingga daya minat dan daya beli batik bakaran menjadi rendah yang kurang mengikuti trend yang ada di pasaran (wawancara 1 Agustus 2017).

\section{SIMPULAN DAN SARAN}

\section{Simpulan}

Batik Bakaran merupakan batik unggulan Kab. Pati hanya saja pengrajin batik belum mengolah potensi tersebut secara maksimal. Batik bakaran masih sebatas digunakan untuk cenderamata dan produk unggulan di Kabupaten Pati yang belum menunjukkan perkembangan yang baik di industri nasional maupun global. Pada tahun 2009 adanya program pemerintah ekonomi kreatif yang mengikutsertakan batik bakaran termasuk kedalam ekonomi kreatif. Pengembangan batik bakaran melalui program ekonomi kreatif mengacu pada Intruksi Presiden No. 6 tahun 2009 tentang pengembangan ekonomi kreatif tahun 2009 - 2015. Ekonomi kreatif sangat diperlukan untuk mendorong daya saing Batik Bakaran lebih kuat dan berkualitas sehingga mampu bersaing di tingkat nasional maupun global. Batik sudah mulai menunjukkan perkembangan yang baik di pasar nasional dengan permintaan batik yang cukup tinggi dan dapat bersaing dengan batik nasional seperti batik Yogyakarta, Solo, Pekalongan dan Lasem. Meskipun belum semua pengrajin batik dapat mengembangkan inovasi dan menciptakan motif baru batik yang sesuai dengan minat konsumen. Kemampuan pengrajin batik dalam melakukan inovasi sangat dipengaruhi dengan kualitas SDM.

Dalam ekonomi kreatif yang harus dikembangkan adalah ide kreatif dari SDM, melalui gagasan, daya kreasi dan daya cipta untuk meningkatkan 
kemampuan dan kualitas pengrajin batik. Hal ini yang menjadikan sumber dukungan pemerintah melalui program ekonomi kreatif dengan meningkatkan kualitas SDM pengrajin batik. Ada beberapa dukungan dari pemerintah Kab. Pati berupa bantuan pelatihan manajemen penjualan, pelatihan promosi, pewarnaan batik bakaran. Dukungan pemerintah melalui program ekonomi kreatif dapat meningkatkan produktivitas batik bakaran tidak hanya dengan pelatihan SDM pengarajin batik tetapi juga menyediakan fasilitas promosi dan penjualan bagi pengrajin dan pelaku usaha batik berupa stand atau bazar batik.

Perkembangan Batik Bakaran sudah menunjukkan peningkatan dalam produksi serta penjualan. Namun, setiap pengrajin batik mempunyai kemampuan dalam pemasaran serta wilayah pemasaran yang berbeda-beda, karena setiap pelaku usaha dan pengrajin batik saling bersaing satu sama lain.

Hambatan dalam pengembangan batik bakaran melalui program ekonomi kreatif belum berorientasi pada kualitas sumber daya manusia (minimnya inovasi), kegiatan ekonominya masih terbatas pada sulitnya pengrajin batik bakaran dalam (1) kemampuan memperkokoh posisi pasarnya, (2) kemampuan menghubungkan dengan lingkungannya, (3) kemampuan meningkatkan kinerja tanpa henti, dan (4) kemampuan menegakkan posisi yang menguntungkan.

\section{Saran}

1. Pelatihan SDM pengrajin Batik Bakaran melalui ekonomi kreatif yang diberikan oleh pemerintah Kab.
Pati diharapkan mampu meningkatkan akses pasar industri nasional dengan cara memanfaatkan berbagai sumber daya, meningkatnya industri pasar batik bakaran harapannya dapat meningkatkan kualitas serta meningkatkan daya saing produk unggulan batik bakaran.

2. Dengan meningkatnya kualitas Batik Bakaran diharapkan pemerintah Kabupaten Pati membuka peluang usaha bagi masyarakat untuk menjadi pelaku usaha atau pengrajin batik bakaran dalam rangka memperluas produksi batik bakaran.

3. Untuk memperluas industri batik bakaran pemerintah Kab. Pati seharusnya memberi solusi terkait pemasaran batik bakaran melalui teknologi.

\section{DAFTAR PUSTAKA}

Creative Economy Report. (2008). The Challenge Assesing the Creative Economy Towards Informed Policy Making. UNDP, UNCTAD.

Howkins, J. (2001). The Creative Economy: How People Make Money from Ideas.Penguins Books, London. Saeful, Rahmat, Pupu. (2009). Penelitian Kualitatif. Jurnal Equiblibrium. Vol. 5, No. 9. Diakses dari: http://yusuf.staff.ub.ac.id/files/201 2/11/Jurnal-PenelitianKualitatif.pdf

S. Hamidin. (2010). Batik Warisan Budaya Asli Indonesia. Yogyakarta : Narasi.

Saksoko H Moleong, Lexy J. 2002. Metodologi Penelitian Kualitatif. Bandung : Remaja Rusda Karya.

Timbul Haryono. 2008. Seni Pertunjukan dan Seni Rupa dalam Perspektif 


\section{Jurnal Ilmu Pemerintahan, 2 (2), Oktober 2017 - 134}

Usisa Rohmah ${ }^{1}$, Ardli Johan Kusuma ${ }^{2}$, Fachry Rohilie ${ }^{3}$

Arkeologi Seni. Yogyakarta : ISI Press Solo.

UNCTAD (2004). Creative Industries and Development. São Paulo: United Nations.

United Nations. (2010). Creative Economy Report 2010. Creative Economy: A Feasible Development Option. Collaborative EffortLedby United Nations Conference on Trade and Development (UNCTAD) and United Nation Development Programe (UNDP) Special Unitfor South-South Cooperation. Diunduh hari rabu, 26 Juli 2017 dari:http://www.unctad.org/creativ e-economy.

\section{Media Massa:}

www.finance.detik.com, 2017. Ikm Batik Serap Hampir 200000 Tenaga Kerja, diakses pada 10 Mei 2017. Dari https://finance.detik.com/beritaekonomi-bisnis/d-3034022/ada47000-ikm-batik-serap-hampir200000-tenaga-kerja.

www.uph.edu.com, 2012. Batik Sebagai Identitas Bangsa Indonesia. Diakses pada 2 Februari 2017. Dari http://www.uph.edu/id/componen t/wmnews/new/1270.html.

www.patikab.go.id, 2014. Sejarah Batik Bakaran Juwana Pati. Diakses pada tanggal 3 Mei 2017. Dari https://www.patikab.go.id/v2/id/2 014/08/09/sejarah-batik-bakaranjuwanapati/

www.travel.tempo.com, 2013. Batik bakaran pati dari pasar lokal ke turis. Diakses pada tanggal 21 Juni 2017.

Dari

https://travel.tempo.co/read/news

/2013/03/15/198467250/batik-

bakaran-pati-dari-pasar-lokal-ke-

turis

www. Pikiran-rakyat.com, 2017. Jabar jadi salah satu objek survei data ekonomi kreatif. Diakses pada tanggal 23 juni 2017. Dari http://www.pikiranrakyat.com/jawabarat/2017/07/06/jabar-jadisalah-satu-objek-survei-dataekonomi-kreatif-404619

\section{PROFIL SINGKAT}

\section{Usisa Rohmah., S.Ip., M.Si}

Lahir di Magelang 9 Februari 1989, Dosen Ilmu Pemerintahan pada Universitas 17 Agustus 1945 Jakarta. Menempuh pendidikan S1 Jurusan Ilmu Pemerintahan pada Fakultas Ilmu Sosial Dan Ilmu Politik Universitas Diponegoro Semarang tahun (2007-2011), dan pendidikan S2 Jurusan Ilmu Politik Universitas Diponegoro Semarang tahun (2012-2014). Mulai mengajar di Universitas 17 Agustus 1945 Jakarta tahun 2014 sampai sekarang. 